\title{
PENGARUH PEMBERIAN PUPUK NPK MUTIARA DAN BANYAKNYA BIJI PER LUBANG TANAMTERHADAP PERTUMBUHAN DAN PRODUKSI KACANG TANAH VARIETAS TASIA I (Arachis hypogaea L.)
}

\author{
Oleh: \\ Yustina S. K. Gulo ${ }^{1)}$ \\ Robert G. Marpaung 2) \\ Agnes I. Manurung 3) \\ Universitas Darma Agung, Medan 1,2,3) \\ E-mail: \\ yustinagulo@gmail.com ${ }^{1)}$ \\ ${\frac{\text { marpaumgpertanian@gmail.com }}{\text { agnesmanurung@gmail.com }^{3)}}}^{2)}$
}

\begin{abstract}
This study aims to obtain the correct dosage of NPK Mutiara fertilizer and the number of seeds per planting hole on the growth and production of peanut plants of Tasia 1. The research was conducted on Jl. Binjai $\mathrm{km}$. 10.8, namely the Experimental Field of the Faculty of Agriculture, Darma Agung University, Sunggal Subdistrict, Deli Serdang Regency with a height of $\square 28 \mathrm{~m}$ above sea level, starting from April to August 2020. This research method used a randomized block design (RAK). factorial consisting of two factors. The first factor is the dosage treatment of NPK Mutiara (N) fertilizer consisting of 4 levels, namely: $N 0=0 \mathrm{~g} /$ plot $(0 \mathrm{~kg} / \mathrm{ha}), \mathrm{N1}=15 \mathrm{~g} / \mathrm{plot}(100 \mathrm{~kg} / \mathrm{ha}), \mathrm{N} 2=30 \mathrm{~g} / \mathrm{plot}$ $(200 \mathrm{~kg} / \mathrm{ha})$ and $\mathrm{N3}=45 \mathrm{~g} /$ plot $(300 \mathrm{~kg} / \mathrm{ha})$. The second factor is the treatment of the number of seeds per planting hole (B) consisting of 3 levels, namely: $B 1=1$ seed / planting hole, $B 2=2$ seeds / planting hole and B3=3 seeds / planting hole. The results showed that the treatment of NPK Mutiara fertilizer up to $45 \mathrm{~g} /$ plot had a significant effect on plant height, number of main branches, flowering age, number of gynophores per plant, number of empty pods per plant, total number of pods per plant, pod weight per plot and weight of 100 seeds. Treatment of the number of seeds per planting hole had a significant effect on the number of main branches, flowering age, number of gynophores per plant, total number of pods per plant, pod weight per plot and weight of 100 seeds, but had no significant effect on plant height and number of pods. vacuum per plant. The combination treatment of NPK Mutiara fertilizer and the number of seeds per planting hole did not significantly affect the growth and production of peanuts.
\end{abstract}

Key words: NPK fertilizer, number of seeds per planting hole and peanuts

\footnotetext{
ABSTRAK

Penelitian ini bertujuan untuk mendapatkan dosis pupuk NPK Mutiara dan banyaknya biji per lubang tanam yang tepat terhadap pertumbuhan dan produksi tanaman kacang tanah vareitas Tasia 1. Penelitian dilaksanakan di J1. Binjai km. 
10,8 yaitu Lahan Percobaan Fakultas Pertanian, Universitas Darma Agung, Kecamatan Sunggal, Kabupaten Deli Serdang dengan ketinggian tempat $\pm 28 \mathrm{~m}$ di atas permukaan laut, yang dimulai dari bulan April hingga bulan Agustus 2020. Metode penelitian ini menggunakan Rancangan Acak Kelompok (RAK) faktorial yang terdiri dari dua faktor. Faktor pertama adalah perlakuan dosis pupuk NPK Mutiara $(\mathrm{N})$ terd iri atas 4 taraf yaitu : $\mathrm{N}_{0}=0 \mathrm{~g} / \mathrm{plot}(0 \mathrm{~kg} / \mathrm{ha}), \mathrm{N}_{1}=15 \mathrm{~g} / \mathrm{plot}(100$ $\mathrm{kg} / \mathrm{ha}), \mathrm{N}_{2}=30 \mathrm{~g} / \mathrm{plot}(200 \mathrm{~kg} / \mathrm{ha})$ dan $\mathrm{N}_{3}=45 \mathrm{~g} / \mathrm{plot}(300 \mathrm{~kg} / \mathrm{ha})$. Faktor kedua adalah perlakuan banyaknya biji per lobang tanam (B) terdiri atas 3 taraf yaitu : $\mathrm{B}_{1}=1 \mathrm{biji} /$ lobang tanam, $\mathrm{B}_{2}=2 \mathrm{biji} /$ lobang tanam dan $\mathrm{B}_{3}=3 \mathrm{biji} /$ lobang tanam. Hasil penelitian menunjukkan bahwa, perlakuan pemberian pupuk NPK Mutiara hingga $45 \mathrm{~g} /$ plot berpengaruh nyata terhadap tinggi tanaman, jumlah cabang utama, umur berbunga, jumlah ginofor per tanaman, jumlah polong hampa per tanaman, jumlah polong total per tanaman, bobot polong per plot dan bobot 100 biji.Perlakuan banyaknya biji per lubang tanam berpengaruh nyata terhadap jumlah cabang utama, umur berbunga, jumlah ginofor per tanaman, jumlah polong total per tanaman, bobot polong per plot dan bobot 100 biji, tetapi berpengaruh tidak nyata terhadap tinggi tanaman dan jumlah polong hampa per tanaman. Perlakuan kombinasi pemberian pupuk NPK Mutiara dan banyaknya biji per lubang tanam tidak berpengaruh nyata terhadap pertumbuhan dan produksi kacang tanah.

Kata kunci : pupuk NPK, banyaknya biji per lubang tanam dan kacang tanah

\section{PENDAHULUAN}

Kacang tanah adalah tanaman leguminoceae yang sudah dikenal dan dibudidayakan di Indonesia. Kacang tanah mempunyai nilai ekonomis yang tinggi, sebab mempunyai kandungan lemak, protein, karbohidrat serta vitamin (B1 dan K), dan mengandung mineral yang relatif tinggi (Fachrista dan Issukindarsyah, 2011). Kebutuhan kacang tanah dari tahun ke tahun meningkat sekitar 4,4\% sedangkan produksi kacang tanah hanya meningkat sebesar 2,5\% (Wijayanarko, dkk., 2011). Kacang tanah (Arachis hypogaea L.) merupakan tanaman polongpolongan atau komoditas kacangkacangan yang bernilai ekonomi cukup tinggi dan merupakan salah satu sumber protein dalam pola pangan penduduk Indonesia. Kacang tanah mengandung lemak 40-50\%, protein $27 \%$, karbohidrat $18 \%$, dan vitamin (Marzuki, 2009). Kacang tanah dimanfaatkan sebagai bahan pangan konsumsi langsung atau campuran makanan seperti roti, bumbu dapur, bahan baku industri, dan pakan ternak, sehingga kebutuhan kacang tanah terus meningkat setiap tahunnya sejalan dengan peningkatan jumlah penduduk (Balitkabi, 2013). Produksi kacang tanah dalam negeri belum mampu mencukupi kebutuhan sehingga Indonesia masih memerlukan substitusi impor dari luar negeri. Oleh sebab itu pemerintah terus berupaya meningkatkan jumlah produksi dalam negeri melalui intensifikasi, perluasan areal pertanaman, penggunaan bibit unggul, pemeliharaan yang baik dan 
pemupukan yang tepat (Adisarwanto, 2003).

Produksi rata-rata kacang tanah di Indonesia dari tahun 2014 hingga 2018 mengalami penurunan. Pada tahun 2014, produksi kacang tanah sekitar 638.896 ton/tahun dan di setiap tahunnya terjadi penurunan produksi hingga pada tahun 2018 menjadi 512.198 ton/tahun. Pada daerah Sumatera Utara, produksi kacang tanah pada tahun 2014 mencapai 9.777 ton, tahun 2015 turun menjadi 8.517 ton, dan 3 tahun berturut-turut dari 2016 - 2018 menjadi 4.870 ton untuk tahun 2016, 4.380 ton untuk tahun 2017, dan 4.323 ton untuk tahun 2018 (Badan Pusat Statistik, 2019). Kebutuhan kacang tanah dari tahun ke tahun terus meningkat sejalan dengan bertambahnya jumlah penduduk, kebutuhan gizi masyarakat, pangan, serta meningk atnya kapasitas industri pakan dan makanan di Indonesia (BPS, 2019). Produktivitas kacang tanah di Indonesia relatif rendah sekitar 1,0 ton/ha di tingkat petani dan 2,5 ton/ha pada tingkat percobaan. Rendahnya produksi kacang tanah di Indonesia disebabkan oleh beberapa faktor seperti rendahnya kualitas benih, kurangnya pengetahuan petani tentang pemupukan, ketersediaan varietas unggul yang masih terbatas, pengelolaan tanah, rendahnya bahan organik, pembuatan drainase yang buruk (tingginya pencucian), periode kekeringan yang cukup lama. Di samping hal di atas pemberian pupuk dalam bentuk pupuk organik dan pupuk anorganikmerupakan hal penting dalam peningkatan produksi kacang tanah (Suprapto dkk, 2018).Pemupukan merupakan salah satu teknik yang menentukan tingkat pertumbuhan suatu tanaman. Tanah mengandung unsur hara tersedia dalam jumlah terbatas. Sebagian besar kebutuhan hara harus dipenuhi melalui pemupukan. Pemupukan bertujuan untuk menjaga dan meningkatkan ketersediaan zat yang berisi satu unsur hara atau lebih dalam tanah yang dimaksudkan untuk menggantikan unsur hara yang habis terserap dari dalam tanah sehingga tanaman akan tumbuh dengan baik dan akan mampu berpotensi secara maksimal (Novizan, 2010).

Pupuk NPK Mutiara merupakan salah satu pupuk anorganik yang mengandung lebih dari satu unsur hara, sehingga pupuk ini disebut juga pupuk majemuk. Pupuk NPK mengandung unsur hara, nitrogen, fospor, dan kalium. Pupuk ini sangat baik untuk mendukung masa pertumbuhan tanaman. Pupuk NPK mutiara (16:16:16) merupakan salah satu pupuk anorganik bersifat majemuk yang memiliki unsur hara makro $\mathrm{N}, \mathrm{P}$, dan $\mathrm{K}$ masing-masing $16 \%$ (Fahmi, 2014).Pengaturan jumlah benih per lubang tanam merupakan suatu cara yang sederhana untuk mengatur cahaya yang diterima oleh tanaman. Umumnya biomasa akan meningkat per satuan luas yang tercapai pada awal pertumbuhan karena kepadatan yang tinggi, sehingga penggunaan cahaya lebih maksimal, tetapi akhirnya sifat tiap-tiap induk menurun karena persaingan cahaya dan faktor-faktor tumbuh lain, dalam hal ini respon ditunjukan dengan menurunnya ukuran tanaman atau bagian lainnya. 
Berdasarkan latar belakang tersebut, maka penulis tertarik dan memilih untuk melakukan penelitian tentang "Pengaruh Pemberian Pemberian Pupuk NPK Mutiara dan Banyaknya Biji per Lubang Tanam terhadap Pertumbuhan dan Produksi Kacang Tanah (Arachis hypogaea L.)".

\section{Tujuan Penelitian}

Penelitian ini bertujuan untuk mendapatkan dosis pupuk NPK Mutiara dan banyaknya biji per lubang tanam yang tepat terhadap pertumbuhan dan produksi tanaman kacang tanah (Arachis hypogaea L.).

\section{Hipotesis Penelitian}

1. Ada pengaruh pemberian pupuk NPK Mutiara terhadap pertumbuhan dan produksi tanaman kacang tanah.

2. Ada pengaruh banyaknya biji per lubang tanam terhadap pertumbuhan dan produksi tanaman kacang tanah.

3. Ada interaksi pemberian pupuk NPK Mutiara dan banyaknya biji per lubang tanam terhadap pertumbuhan dan produksi tanaman kacang tanah.

\section{TINJAUAN PUSTAKA \\ Teknologi Budidaya Kacang Tanah}

Tanaman kacang tanah dapat tumbuh pada daerah tropik, subtropik, serta daerah pada $40^{\circ} \mathrm{LU}$ $-40^{\circ}$ LS dengan ketinggian $0-500$ $\mathrm{m}$ di atas permukaan laut. Persyaratan mengenai tanah yang cocok bagi tumbuhnya kacang tanah tidaklah terlalu khusus. Syarat yang terpenting adalah bahwa keadaan tanah tidak terlalu kurus dan padat. Kondisi tanah yang mutlak diperlukan adalah tanah yang gembur. Kondisi tanah yang gembur akan memberikan kemudahan bagi tanaman kacang tanah terutama dalam hal perkecambahan biji, kuncup buah, dan pembentukan polong yang baik. Kondisi tanah yang gembur juga akan mempermudah bakal buah menembus masuk kedalam tanah untuk membentuk polong yang baik (Rukmana, 2007).

Kacang tanah menghendaki keadaan iklim yang panas tetapi sedikit lembab, yaitu rata-rata 65 $75 \%$ dan curah hujan tidak terlalu tinggi, yaitu sekitar $800-1300$ $\mathrm{mm} /$ tahun dengan suhu harian $25-$ $35^{\circ}$ C. Tanaman kacang tanah tumbuh baik pada keadaan $\mathrm{pH}$ tanah sekitar 6-6,5 (Marzuki, 2007).

Adapun syarat-syarat benih atau bibit kacang tanah yang baik yaitu ; a) Berasal dari tanaman yang baru dan varietas unggul, b) Daya tumbuh yang tinggi (lebih dari $90 \%$ ) dan sehat, c) Kulit benih mengkilap, tidak keriput dan cacat, d) Murni atau tidak tercampur dengan varietas lain, e) Kadar air benih berkisar 9 $12 \%$. Pupuk dasar seperti pupuk kandang 2 - 4 ton/ha perlu diberikan pada tanaman kacang tanah yaitu diberikan pada permukaan bedengan kurang lebih seminggu sebelum tanam, dicampur pada tanah bedengan atau diberikan pada lubang tanam. Pupuk anorganik seperti SP$36(100 \mathrm{~kg} / \mathrm{ha})$, Urea (100 kg/ha) dan $\mathrm{KCl}$ (50 kg/ha) (Rukmana, 2007).

\section{Pengaruh Pupuk NPK Mutiara terhadap Pertumbuhan dan Produksi Kacang Tanah}

Peranan pupuk NPK bagi tanaman antara lain: peranan utama 
nitrogen $(\mathrm{N})$ bagi tanaman adalah untuk merangsang pertumbuhan secara keseluruhan, khususnya batang, cabang, dan daun, selain itu, nitrogen berperan penting dalam pembentukan hijau daun yang sangat berguna dalam proses fotosintesis. Fungsi lainnya adalah pembentukan protein, lemak, dan berbagai persenyawaan organik lainnya. Peranan utama fospor (P) bagi tanaman adalah untuk merangsang pertumbuhan akar, khususnya akar benih dan tanaman muda, selain itu, fospor berfungsi sebagai bahan mentah untuk pembentukan sejumlah protein tertentu, membantu simulasi dan pernapasan, serta mempercepat pembungaan, pemasakan biji dan buah. Peranan utama kalium (K) bagi tanaman adalah membantu pembentukan protein dan karbohidrat. Kalium juga berperan dalam memperkuat tubuh tanaman agar daun, bunga dan buah tidak mudah gugur dan juga merupakan sumber kekuatan bagi tanaman dalam menghadapi kekeringan dan penyakit. Gejala kekurangan nitrogen menyebabkan tanaman tumbuh kerdil, daun menjadi hijau muda, terutama daun yang sudah tua lalu berubah menjadi kuning, selanjutnya daun mengering mulai dari bawah kebagian atas tanaman, jaringanjaringanya mati, mengering, lalu merangas. Tanah yang kekurangan fospor meyebabkan warna daun seluruhnya berubah kelewat tua dan sering tampak mengkilap kemerahan. Tepi daun, cabang dan batang terdapar warna merah ungu yang lambat laun berubah menjadi kuning. Tanaman yang tumbuh pada tanah yang kekurangan unsur kalium akan memperlihatkan gejala-gejala seperti daun mengerut terutama pada daun tua walaupun tidak merata (Lingga dan Marsono, 2013).

Penelitian Raharja $\begin{array}{r}\text { dkk., } \\ \text { (2018) menyatakan }\end{array}$ bahwa
matal pemberian pupuk NPK dengan dosis $200 \mathrm{~kg} / \mathrm{ha}$ nyata mempercepat umur berbunga tanaman kacang tanah menjadi 20,40 hari. Penelitian Zulhaedar dkk., (2016) menunjukkan bahwa pemberian pupuk pupuk NPK Phonska dengan dosis $200 \mathrm{~kg} / \mathrm{ha}$ nyata meningkatkan pertumbuhan vegetatif kacang tanah namun tidak berpengaruh terhadap komponen hasil kacang tanah. Tinggi tanaman, bobot sagar akar dan biomas yang diberi pupuk NPK Phonska pada dosis $50 \mathrm{~kg} / \mathrm{ha}, 100 \mathrm{~kg} / \mathrm{ha}, 150 \mathrm{~kg} / \mathrm{ha}$, dan $200 \mathrm{~kg} / \mathrm{ha}$ lebih tinggi dan berbeda nyata dibanding yang tidak diberi Phonska.

\section{Jumlah Biji per Lubang Tanam}

benih Jumlah satu benih dan dua menunjukkan perbedaan yang nyata. Hal ini disebabkan pada perlakuan tiga benih terjadi kompetisi antar tanaman, terutama faktor cahaya. Tanaman berkompetisi satu sama lainnya apabila tanaman tersebut dalam jumlah tanaman yang banyak. Faktor yang dikompetisikan adalah unsur hara, air atau cahaya. Kompetisi antara spesies yang sama menyebabkan tanaman menjadi lebih tinggi dalam kompetisi cahaya, karena sebagai efek naungan yang berat, sedangkan kompetisi antara spesies yang berbeda diekspresikan dengan meningkatnya jumlah tanaman dan ukuran spesies yang dominan. Penelitian Gobel (2015), menunjukkan bahwa jumlah benih 2 butir per lubang tanam memiliki hasil yang lebih baik 
terhadap pertumbuhan kacang tanah yakni tinggi tanaman 4 MST, 6 MST, 8 MST jumlah daun 4 MST, 6 MST, 8 MST dan hasil yakni jumlah polong per tanaman, berat polong kering per tanaman, berat biji kering per tanaman, dan berat 100 biji dibandingkan jumlah benih 1 butir per lubang tanam. Kemampuan kompetisi sangat dipengaruhi oleh sifat tanaman itu sendiri seperti bagaimana sebaran perakaran dari lebar tajuk tanaman. Penelitian Wirawan dkk., (2018) menyatakan bahwa penggunaan jumlah tanaman tiga per lubang memberikan hasil tertinggi pada jumlah polong isi per tanaman, berat polong isi segar per tanaman, berat polong isi kering per tanaman, berat polong isi segar per $\mathrm{m}^{2}$, dan berat polong isi kering per $\mathrm{m}^{2}$ pada tanaman kacang tanah.

\section{METODE PENELITIAN}

Penelitian dilaksanakan di Jl. Binjai km. 10,8 yaitu Lahan Percobaan Fakultas Pertanian, Universitas Darma Agung, Kecamatan Sunggal, Kabupaten Deli Serdang dengan ketinggian tempat \pm $28 \mathrm{~m}$ di atas permukaan laut, yang dimulai dari bulan April hingga bulan Agustus 2020. Metode penelitian ini menggunakan Rancangan Acak Kelompok (RAK) faktorial yang terdiri dari dua faktor dengan 3 kali ulangan. Faktor pertama adalah perlakuan dosis pupuk NPK Mutiara $(\mathrm{N})$ terdiri atas 4 taraf yaitu : $\mathrm{N}_{0}=0 \mathrm{~g} /$ plot, $\mathrm{N}_{1}=15$ g/plot, $\mathrm{N}_{2}=30 \mathrm{~g} /$ plot, $\mathrm{N}_{3}=45 \mathrm{~g} /$ plot. Faktor kedua adalah perlakuan banyaknya biji per lobang tanam (B) terdiri atas 3 taraf yaitu : $\mathrm{B}_{1}=1$ biji/lobang tanam, $\mathrm{B}_{2}=2$ biji/lobang tanam dan $\mathrm{B}_{3}=3$ biji/lobang tanam. Jumlah tanaman per plot sebanyak 15 tanaman dengan jarak tanam 40 $\mathrm{cm} \times 25 \mathrm{~cm}$.

Untuk mengetahui pengaruh dari setiap faktor perlakuan dilakukan uji statistik dengan menggunakan analisis sidik ragam. Jika terdapat pengaruh yang nyata dari setiap faktor perlakuan kemudian dilanjtkan dengan uji beda rataan antar setiap taraf perlakuan dengan uji Duncan. Selanjutnya dilakukan uji regresi dan korelasi pada taraf uji $5 \%$.

\section{HASIL DAN PEMBAHASAN \\ Tinggi Tanaman (cm)}

Rataan tinggi tanaman kacang tanah pada umur 2 - 9 MST akibat perlakuan pemberian pupuk NPK Mutiara dan pupuk NPK disajikan pada Tabel 1.

Tabel 1. Rataan Tinggi Tanaman $(\mathrm{cm})$ akibat Perlakuan Pemberian pupuk NPK Mutiara dan Pupuk NPK pada Umur 2 - 9 MST

\begin{tabular}{ccccccccc}
\hline \multirow{2}{*}{ Perlakuan } & \multicolumn{7}{c}{ Tinggi Tanaman $(\mathrm{cm})$} \\
\cline { 2 - 9 } & 2 MST & 3 MST & 4 MST & 5 MST & 6 MST & 7 MST & 8 MST & 9 MST \\
\hline $\mathrm{N}_{0}$ & 5.91 & 7.94 & 14.81 & 21.83 & 28.23 & 34.52 & $37.38 \mathrm{a}$ & $44.46 \mathrm{a}$ \\
$\mathrm{N}_{1}$ & 5.44 & 7.42 & 14.79 & 21.82 & 28.31 & 34.64 & $38.17 \mathrm{ab}$ & $45.36 \mathrm{ab}$ \\
$\mathrm{N}_{2}$ & 5.47 & 7.42 & 13.95 & 20.99 & 27.26 & 33.74 & $37.56 \mathrm{ab}$ & $45.11 \mathrm{ab}$ \\
$\mathrm{N}_{3}$ & 6.01 & 7.96 & 14.77 & 22.12 & 28.96 & 35.55 & $39.97 \mathrm{~b}$ & $47.33 \mathrm{~b}$ \\
\hline $\mathrm{B}_{1}$ & 5.82 & 7.82 & 14.97 & 22.28 & 28.55 & 34.89 & 38.26 & 45.36 \\
$\mathrm{~B}_{2}$ & 5.75 & 7.69 & 14.44 & 21.66 & 28.24 & 34.39 & 37.75 & 45.36 \\
$\mathrm{~B}_{3}$ & 5.55 & 7.54 & 14.33 & 21.13 & 27.78 & 34.56 & 38.80 & 45.98 \\
\hline
\end{tabular}


Keterangan: Angka yang diikuti oleh huruf yang sama dalam kolom dan kelompok perlakuan yang sama tidak berbeda nya ta pada uji Duncan taraf uji $5 \%$

Pengaruh dosis pupuk NPK Mutiara terhadap tinggi tanaman kacang tanah pada umur 9 MST, diperlihatkan pada Gambar 1.

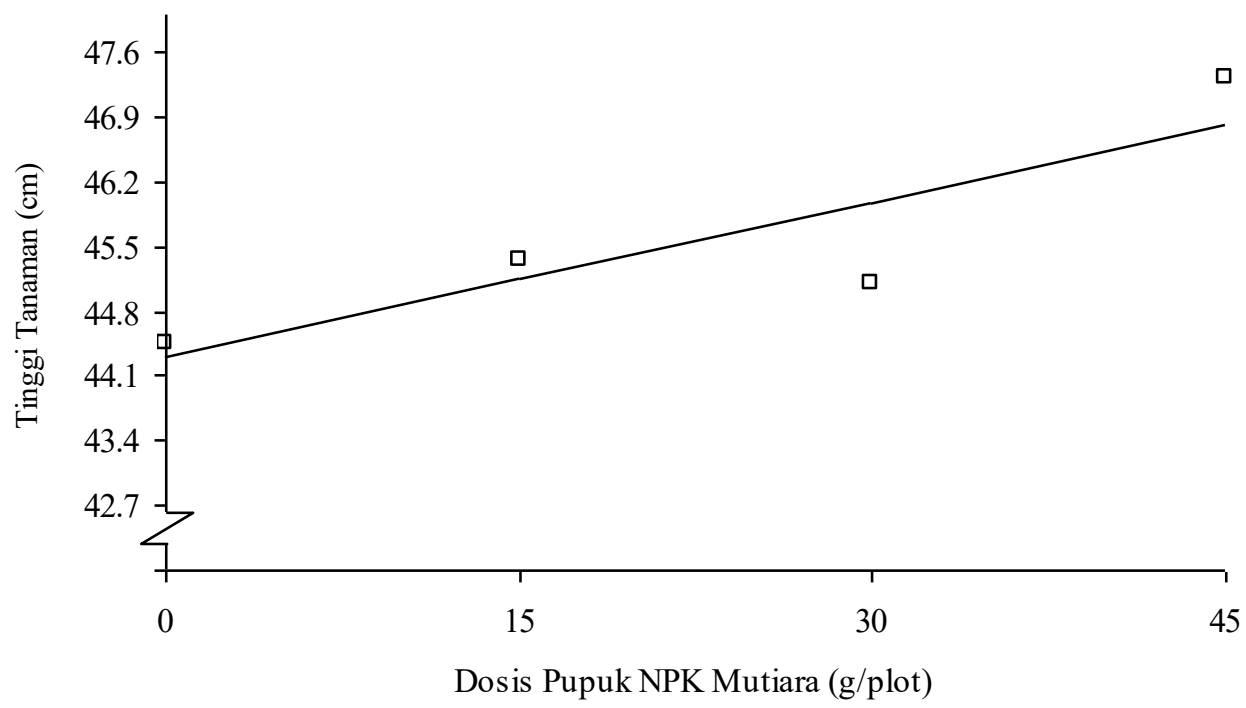

Gambar 1. Kurva Respon Pengaruh Pemberian Pupuk NPK Mutiara terhadap Tinggi Tanaman Kacang Tanah pada Umur 9 Minggu Setelah Tanam

Dari Gambar 1 terlihat bahwa semakin tinggi pemberian pupuk NPK Mutiara maka tinggi tanaman kacang tanah semakin meningkat mengikuti kurva regresi linear positif dengan nilai $r$ sebesar 0.87 . Peningkatan pemberian pupuk NPK

Mutiara sebesar $1 \mathrm{~g} /$ plot maka tinggi tanaman meningkat $0.06 \mathrm{~cm}$.

\section{Jumlah Cabang Utama (tangkai)}

Rataan jumlah cabang utama akibat perlakuan pemberian pupuk NPK Mutiara dan banyaknya biji per lubang tanam disajikan pada Tabel 2.

Tabel 2. Rataan Jumlah Cabang Utama akibat Perlakuan Pemberian Pupuk NPK Mutiara dan Banyaknya Biji per Lubang Tanam (tangkai)

\begin{tabular}{ccccc}
\hline Perlakuan & $\mathrm{B}_{1}$ & $\mathrm{~B}_{2}$ & $\mathrm{~B}_{3}$ & Rataan \\
\hline $\mathrm{N}_{0}$ & 3.00 & 3.07 & 3.07 & $3.04 \mathrm{a}$ \\
$\mathrm{N}_{1}$ & 3.27 & 3.13 & 3.07 & $3.16 \mathrm{ab}$ \\
$\mathrm{N}_{2}$ & 3.67 & 3.27 & 3.13 & $3.36 \mathrm{bc}$ \\
$\mathrm{N}_{3}$ & 3.60 & 3.53 & 3.13 & $3.42 \mathrm{c}$ \\
\hline Rataan & $3.38 \mathrm{~b}$ & $3.25 \mathrm{ab}$ & $3.10 \mathrm{a}$ & \\
\hline
\end{tabular}

Keterangan: Angka yang diikuti oleh huruf yang sama dalam kolom dan kelompok perlakuan yang sama berartitidak berbeda pada ujiDuncan taraf uji $5 \%$ 
Tabel 2 menunjukkan bahwa pada perlakuan pemberian pupuk NPK Mutiara, jumlah cabang utama terbanyak terdapat pada perlakuan $\mathrm{N}_{3}$ berbeda nyata dengan $\mathrm{N}_{0}$, tetapi berbeda tidak nyata dengan $\mathrm{N}_{1}$ dan $\mathrm{N}_{2}$. Hubungan antara pemberian pupuk NPK Mutiara dengan jumlah cabang utama tanaman kacang tanah diperlihatkan pada Gambar 2.

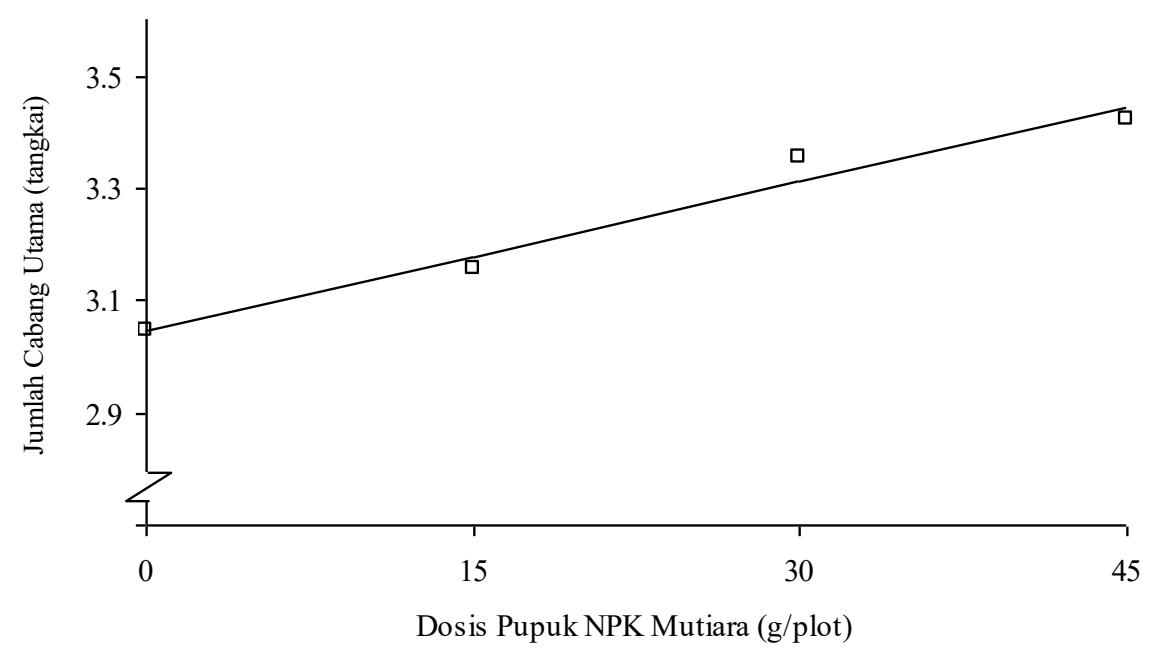

Gambar 2. Kurva Respon Pengaruh Pemberian Pupuk NPK Mutiara terhadap Jumlah Cabang Utama Tanaman Kacang Tanah

Dari Gambar 2 terlihat bahwa semakin tinggi pemberian pupuk NPK Mutiara maka jumlah cabang utama semakin meningkat mengikuti kurva regresi linier positif dengan nilai $\mathrm{r}$ sebesar 0.98. Peningkatan pemberian pupuk NPK Mutiara sebesar $1 \mathrm{~g} / \mathrm{p}$ lot maka jumlah cabang utama tanaman semakin meningkat 0.009 tangkai.
Tabel 2 juga menunjukkan bahwa pada perlakuan banyaknya biji per lubang tanam, jumlah cabang utama terbanyak terdapat pada perlakuan $\mathrm{B}_{1}$ berbeda nyata dengan $\mathrm{B}_{3}$, tetapi berbeda tidak nyata dengan $\mathrm{B}_{2}$. Hubungan antara banyaknya biji per lubang tanam dengan jumlah cabang utama tanaman kacang tanah diperlihatkan pada Gambar 3. 


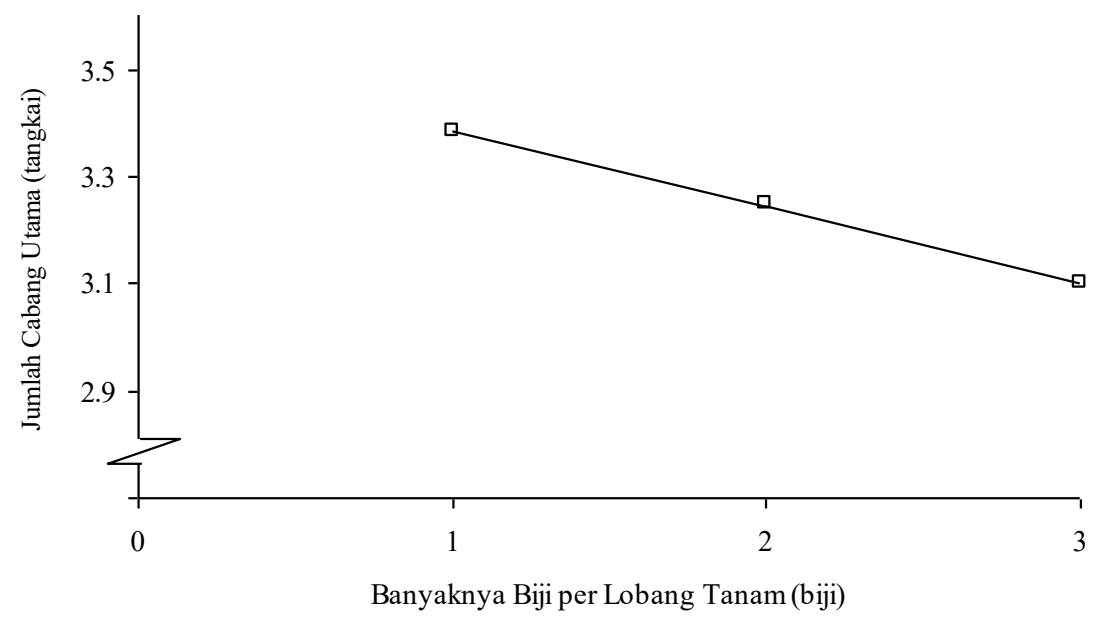

Gambar 3. Kurva Respon Pengaruh Banyaknya Biji per Lubang Tanam terhadap Jumlah Cabang Utama Tanaman Kacang Tanah

Dari Gambar 3 terlihat bahwa semakin banyaknya biji per lubang tanam maka jumlah cabang utama tanaman kacang tanah semakin menurun mengikuti kurva regresi linear negatif dengan nilai $r$ sebesar 0.99. Peningkatan jumlah biji per lubang tanam sebesar 1 biji/lubang tanam maka jumlah cabang utama menurun sebesar 0.14 tangkai.

\section{Umur Berbunga (hari)}

Rataan umur berbunga akibat perlakuan pemberian pupuk NPK Mutiara dan banyaknya biji per lubang tanam disajikan pada Tabel 3.

Tabel 3. Rataan Umur Berbunga Kacang Tanah akibat Perlakuan Pemberian Pupuk NPK Mutiara dan Banyaknya Biji per Lubang Tanam (hari)

\begin{tabular}{ccccc}
\hline Perlakuan & $\mathrm{B}_{1}$ & $\mathrm{~B}_{2}$ & $\mathrm{~B}_{3}$ & Rataan \\
\hline $\mathrm{N}_{0}$ & 27.00 & 27.00 & 27.67 & $27.22 \mathrm{c}$ \\
$\mathrm{N}_{1}$ & 26.00 & 26.67 & 27.00 & $26.56 \mathrm{~b}$ \\
$\mathrm{~N}_{2}$ & 25.67 & 26.33 & 26.67 & $26.22 \mathrm{ab}$ \\
$\mathrm{N}_{3}$ & 26.00 & 26.00 & 26.00 & $26.00 \mathrm{a}$ \\
\hline Rataan & $26.17 \mathrm{a}$ & $26.50 \mathrm{ab}$ & $26.83 \mathrm{~b}$ & \\
\hline
\end{tabular}

Keterangan: Angka yang diikuti oleh huruf yang sama dalam kolom dan kelompok perlakuan yang sama berartitidak berbeda pada ujiDuncan taraf uji $5 \%$

Tabel 3 menunjukkan bahwa pada perlakuan pemberian pupuk NPK Mutiara, umur berbunga tanaman tercepat terdapat pada perlakuan $\mathrm{N}_{3}$ berbeda nyata dengan $\mathrm{N}_{0}$ dan $\mathrm{N}_{1}$, tetapi berbeda tidak nyata dengan $\mathrm{N}_{2}$. Hubungan antara pemberian pupuk NPK Mutiara dengan umur berbunga tanaman kacang tanah diperlihatkan pada Gambar 4. 


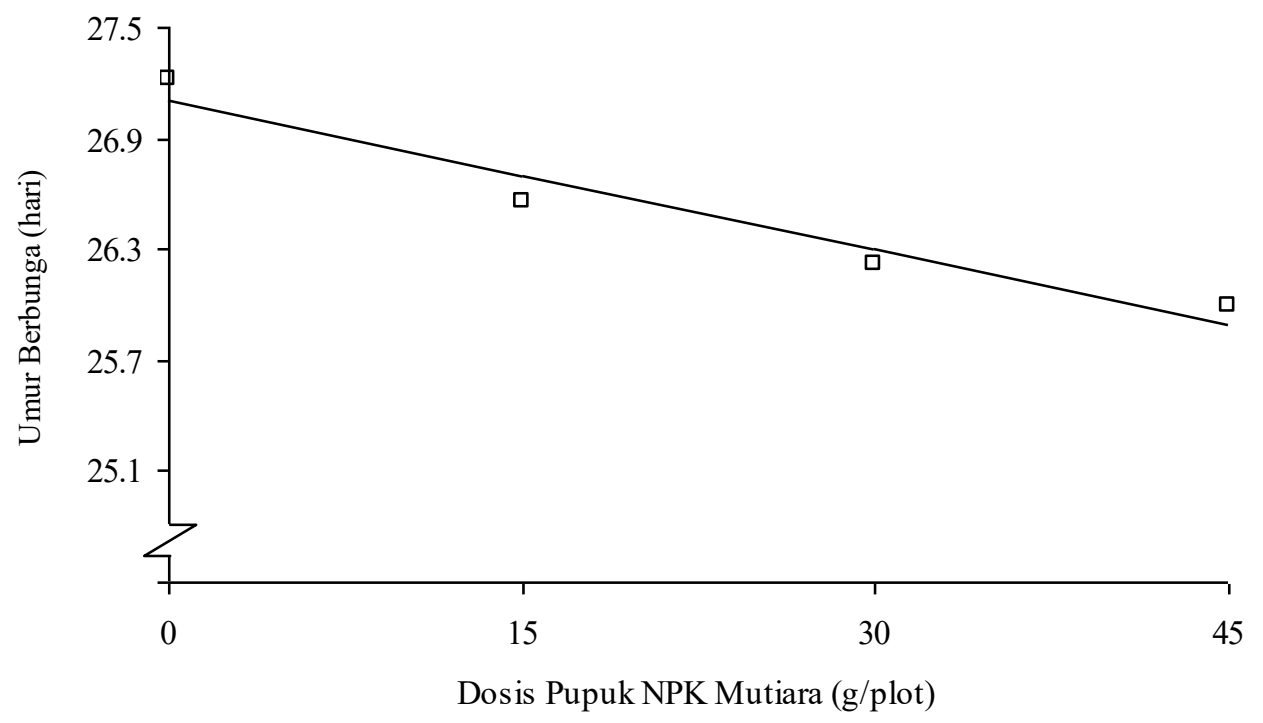

Gambar 4. Kurva Respon Pengaruh Pemberian Pupuk NPK Mutiara terhadap Umur Berbunga Tanaman Kacang Tanah

Dari Gambar 4 terlihat bahwa semakin tinggi pemberian pupuk NPK Mutiara maka umur berbunga semakin cepat mengikuti kurva regresi linier negatif dengan nilai $r$ sebesar 0.97 . Peningkatan pemberian pupuk NPK Mutiara sebesar $1 \mathrm{~g} /$ plot maka umur berbunga semakin cepat 0.03 hari.

Tabel 3 juga menunjukkan bahwa pada perlakuan banyaknya biji per lubang tanam, umur berbunga tercepat terdapat pada perlakuan $\mathrm{B}_{1}$ berbeda nyata dengan $\mathrm{B}_{3}$, tetapi berbeda tidak nyata dengan $\mathrm{B}_{2}$. Umur berbunga tanaman kacang tanah pada perlakuan $\mathrm{B}_{2}$ berbeda tidak nyata dengan $\mathrm{B}_{1}$. Hubungan antara banyaknya biji per lubang tanam dengan umur berbunga tanaman kacang tanah diperlihatkan pada Gambar 5.

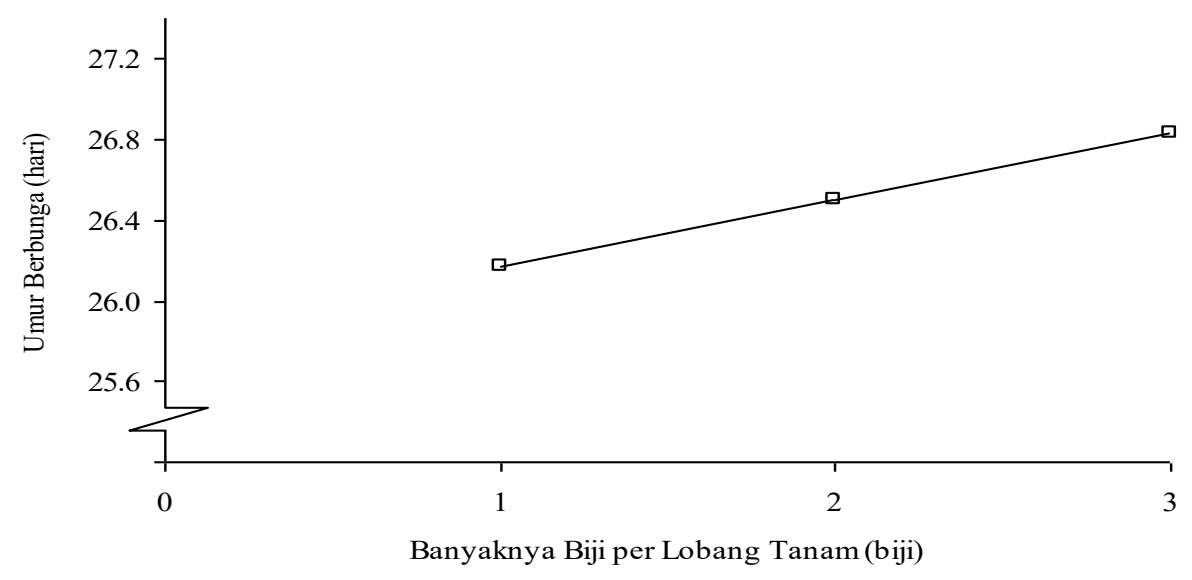

Gambar 5. Kurva Respon Pengaruh Banyaknya Biji per Lubang Tanam terhadap Umur Berbunga Tanaman Kacang Tanah 
Dari Gambar 5 terlihat bahwa semakin banyaknya biji per lubang tanam maka umur berbunga tanaman kacang tanah semakin meningkat mengikuti kurva regresi linear positif dengan nilai $r$ sebesar 0.99 . Peningkatan jumlah biji per lubang tanam sebesar 1 biji/lubang tanam maka umur berbunga tanaman kacang tanah meningkat sebesar 0.33 hari.

\section{Jumlah Ginofor per Tanaman (buah)}

Rataan jumlah ginofor per tanaman akibat perlakuan pemberian pupuk NPK Mutiara dan banyaknya biji per lubang tanam disajikan pada Tabel 5.

Tabel 4. Rataan Jumlah Ginofor per Tanaman akibat Perlakuan Pemberian Pupuk NPK Mutiara dan Banyaknya Biji per Lubang Tanam (buah)

\begin{tabular}{ccccc}
\hline Perlakuan & $\mathrm{B}_{1}$ & $\mathrm{~B}_{2}$ & $\mathrm{~B}_{3}$ & Rataan \\
\hline $\mathrm{N}_{0}$ & 25.80 & 25.33 & 25.07 & $25.40 \mathrm{a}$ \\
$\mathrm{N}_{1}$ & 27.13 & 27.73 & 26.07 & $26.98 \mathrm{~b}$ \\
$\mathrm{~N}_{2}$ & 28.20 & 27.73 & 27.73 & $27.89 \mathrm{~b}$ \\
$\mathrm{~N}_{3}$ & 29.33 & 28.53 & 26.27 & $28.04 \mathrm{~b}$ \\
\hline Rataan & $27.62 \mathrm{~b}$ & $27.33 \mathrm{~b}$ & $26.28 \mathrm{a}$ & \\
\hline
\end{tabular}

Keterangan: Angka yang diikuti oleh huruf yang sama dalam kolom dan kelompok perlakuan yang sama berartitidak berbeda pada ujiDuncan taraf uji $5 \%$

Tabel 4 menunjukkan bahwa pada perlakuan pemberian pupuk NPK Mutiara, jumlah ginofor per tanaman terbanyak terdapat pada perlakuan $\mathrm{N}_{3}$ berbeda nyata dengan $\mathrm{N}_{0}$, tetapi berbeda tidak nyata dengan $\mathrm{N}_{1}$ dan $\mathrm{N}_{2}$. Hubungan antara pemberian pupuk NPK Mutiara dengan jumlah ginofor per tanaman diperlihatkan pada Gambar 6.

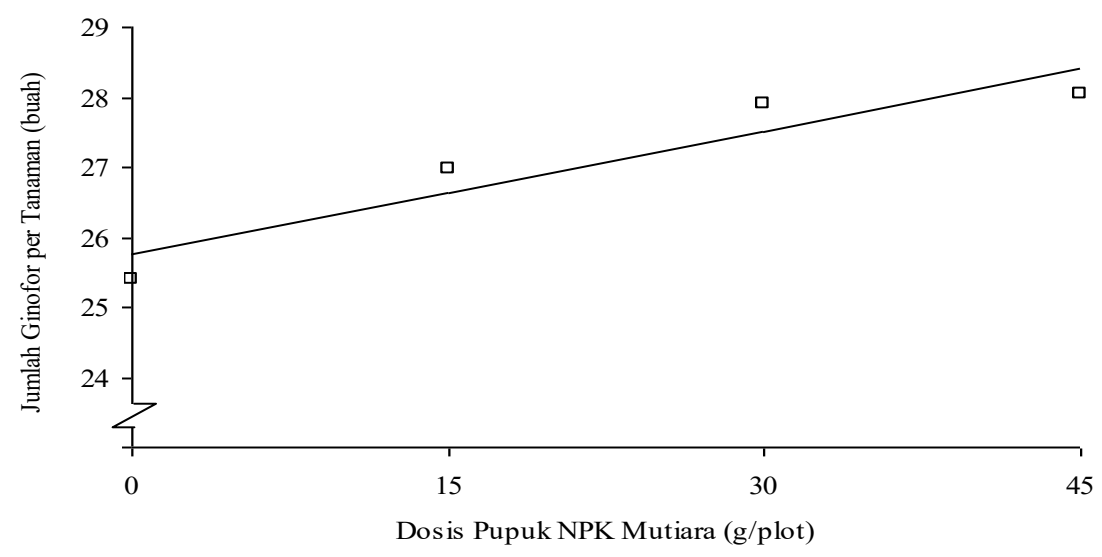

Gambar 6. Kurva Respon Pengaruh Pemberian Pupuk NPK Mutiara terhadap Jumlah Ginofor per Tanaman 
Dari Gambar 6 terlihat bahwa semakin tinggi pemberian pupuk NPK Mutiara maka jumlah ginofor per tanaman semakin meningkat mengikuti kurva regresi linier positif dengan nilai $r$ sebesar 0.94 . Peningkatan pemberian pupuk NPK Mutiara sebesar $1 \mathrm{~g} /$ plot maka jumlah ginofor per tanaman meningkat 0.06 buah.

Tabel 5 juga menunjukkan bahwa pada perlakuan banyaknya biji per lubang tanam, jumlah ginofor per tanaman terbanyak terdapat pada perlakuan $\mathrm{B}_{1}$ berbeda nyata dengan $\mathrm{B}_{3}$, tetapi berbeda tidak nyata dengan $\mathrm{B}_{2}$. Jumlah ginofor per tanaman pada perlakuan $\mathrm{B}_{2}$ berbeda nyata dengan $\mathrm{B}_{1}$. Hubungan antara banyaknya biji per lubang tanam dengan jumlah ginofor per tanaman diperlihatkan pada Gambar 7.

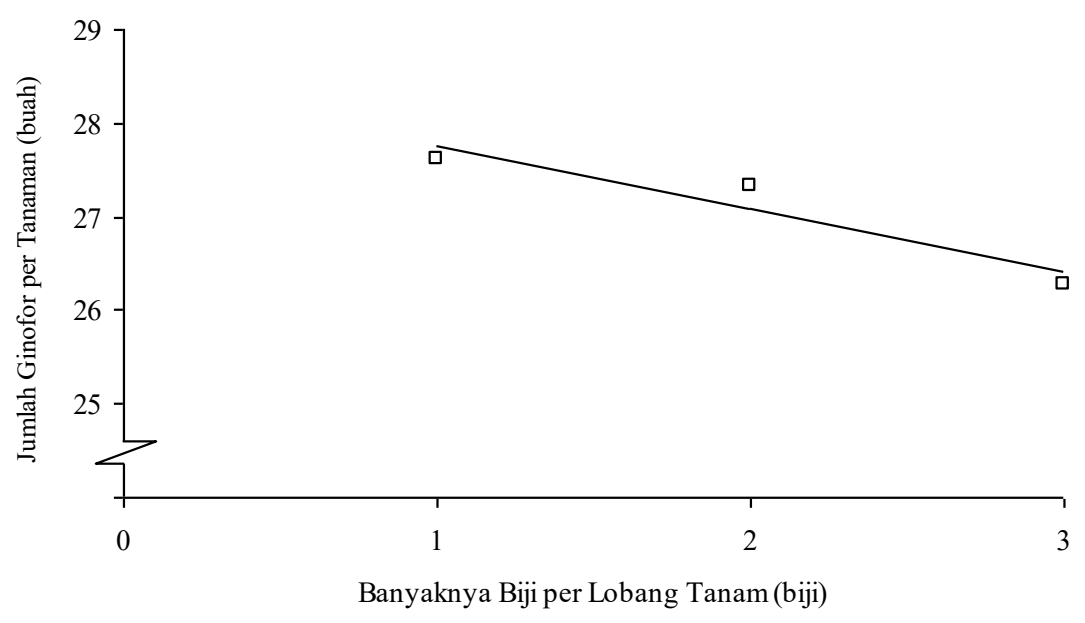

Gambar 7. Kurva Respon Pengaruh Banyaknya Biji per Lubang Tanam terhadap Jumlah Ginofor per Tanaman

Dari Gambar 7 terlihat bahwa semakin banyaknya biji per lubang tanam maka jumlah ginofor per tanaman semakin meningkat mengikuti kurva regresi linear negatif dengan nilai $r$ sebesar -0.95 . Peningkatan jumlah biji per lubang tanam sebesar 1 biji/lubang tanam maka jumlah ginofor per tanaman menurun sebesar 0.67 buah.

\section{Jumlah Polong Berisi per Tanaman (polong)}

Rataan jumlah polong berisi per tanaman akibat perlakuan pemberian pupuk NPK Mutiara dan banyaknya biji per lubang tanam disajikan pada Tabel 5 . 
Tabel 5. Rataan Jumlah Polong Berisi per Tanaman akibat Perlakuan Pemberian Pupuk NPK Mutiara dan Banyaknya Biji per Lubang Tanam (polong)

\begin{tabular}{ccccc}
\hline Perlakuan & $\mathrm{B}_{1}$ & $\mathrm{~B}_{2}$ & $\mathrm{~B}_{3}$ & Rataan \\
\hline $\mathrm{N}_{0}$ & 16.53 & 15.80 & 14.93 & $15.76 \mathrm{a}$ \\
$\mathrm{N}_{1}$ & 18.40 & 17.53 & 15.47 & $17.13 \mathrm{~b}$ \\
$\mathrm{~N}_{2}$ & 18.53 & 18.27 & 16.13 & $17.64 \mathrm{~b}$ \\
$\mathrm{~N}_{3}$ & 18.93 & 17.87 & 17.60 & $18.13 \mathrm{~b}$ \\
\hline Rataan & $18.10 \mathrm{~b}$ & $17.37 \mathrm{~b}$ & $16.03 \mathrm{a}$ & \\
\hline
\end{tabular}

Keterangan: Angka yang diikuti oleh huruf yang sama dalam kolom dan kelompok perlakuan yang sama berartitidak berbeda pada ujiDuncan taraf uji $5 \%$

Tabel 5 menunjukkan bahwa $\mathrm{N}_{0}$, tetapi berbeda tidak nyata dengan $\mathrm{N}_{1}$ dan $\mathrm{N}_{2}$. Hubungan antara pada perlakuan pemberian pupuk NPK Mutiara, jumlah polong berisi per tanaman terbanyak terdapat pada perlakuan $\mathrm{N}_{3}$ berbeda nyata dengan pemberian pupuk NPK Mutiara dengan jumlah polong berisi per tanamaN.

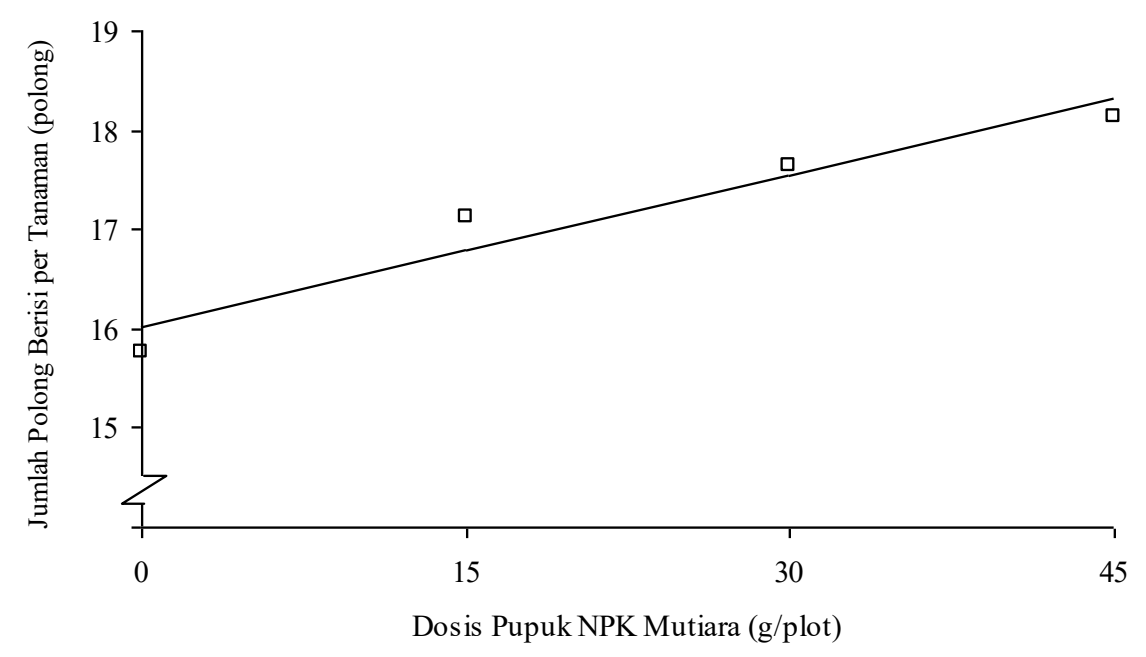

Gambar 8. Kurva Respon Pengaruh Pemberian Pupuk NPK Mutiara terhadap Jumlah Polong Berisi per Tanaman

Dari Gambar 8 terlihat bahwa semakin tinggi pemberian pupuk NPK Mutiara maka jumlah polong berisi per tanaman semakin meningkat mengikuti kurva regresi linier positif dengan nilai $\mathrm{r}$ sebesar 0.96. Peningkatan pemberian pupuk NPK Mutiara sebesar $1 \mathrm{~g} / \mathrm{plot}$ maka jumlah polong berisi per tanaman meningkat 0.05 polong.Juga menunjukkan bahwa pada perlakuan banyaknya biji per lubang tanam, jumlah polong berisi per tanaman terbanyak terdapat pada perlakuan $\mathrm{B}_{1}$ berbeda nyata dengan $B_{3}$, tetapi berbeda tidak nyata dengan $\mathrm{B}_{2}$. Jumlah polong berisi per tanaman pada perlakuan $\mathrm{B}_{2}$ berbeda nyata dengan $B_{1}$. Hubungan antara banyaknya biji per lubang tanam 
dengan jumlah polong berisi per 9. tanaman diperlihatkan pada Gambar

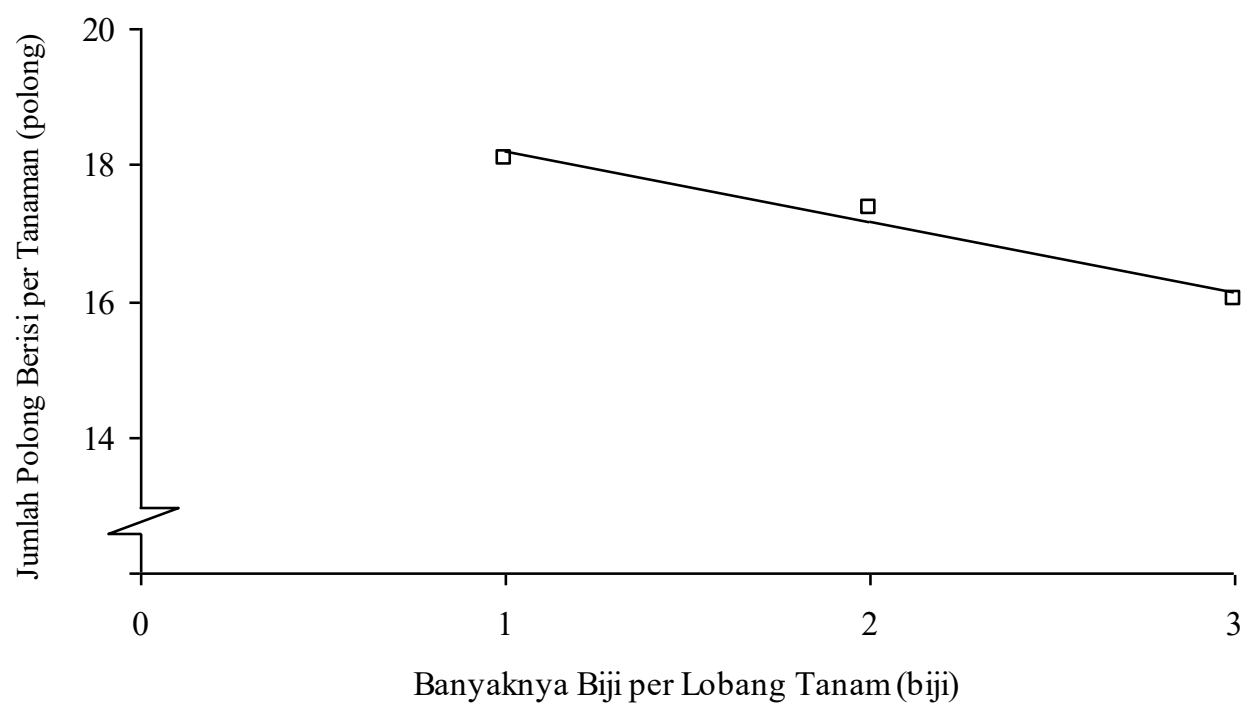

Gambar 9. Kurva Respon Pengaruh Banyaknya Biji per Lubang Tanam terhadap Jumlah Polong Berisi per Tanaman

Dari Gambar 9 terlihat bahwa tanaman menurun sebesar 1.03 semakin banyaknya biji per lubang tanam maka jumlah polong berisi per tanaman semakin meningkat mengikuti kurva regresi linear negatif dengan nilai $\mathrm{r}$ sebesar -0.98 . Peningkatan jumlah biji per lubang tanam sebesar 1 biji/lubang tanam maka jumlah polong berisi per polong.

\section{Jumlah Polong Hampa per Tanaman (polong)}

Rataan jumlah polong hampa per tanaman akibat perlakuan pemberian pupuk NPK Mutiara dan banyaknya biji per lubang tanam disajikan pada Tabel 6 .

Tabel 6. Rataan Jumlah Polong Hampa per Tanaman akibat Perlakuan Pemberian Pupuk NPK Mutiara dan Banyaknya Biji per Lubang Tanam (polong)

\begin{tabular}{ccccc}
\hline Perlakuan & $\mathrm{B}_{1}$ & $\mathrm{~B}_{2}$ & $\mathrm{~B}_{3}$ & Rataan \\
\hline $\mathrm{N}_{0}$ & 4.53 & 4.53 & 4.53 & $4.53 \mathrm{~b}$ \\
$\mathrm{~N}_{1}$ & 4.47 & 4.53 & 4.47 & $4.49 \mathrm{~b}$ \\
$\mathrm{~N}_{2}$ & 4.33 & 4.40 & 4.40 & $4.38 \mathrm{ab}$ \\
$\mathrm{N}_{3}$ & 3.93 & 4.20 & 4.07 & $4.07 \mathrm{a}$ \\
\hline Rataan & 4.32 & 4.42 & 4.37 & \\
\hline
\end{tabular}

Keterangan: Angka yang diikuti oleh huruf yang sama dalam kolom dan kelompok perlakuan yang sama berartitidak berbeda pada ujiDuncan taraf uji $5 \%$ 
Tabel 5 menunjukkan bahwa pada perlakuan pemberian pupuk NPK Mutiara, jumlah polong hampa per tanaman terbanyak terdapat pada perlakuan $\mathrm{N}_{3}$ berbeda nyata dengan $\mathrm{N}_{0}$ dan $\mathrm{N}_{1}$, tetapi berbeda tidak nyata dengan $\mathrm{N}_{2}$. Hubungan antara pemberian pupuk NPK Mutiara dengan jumlah polong hampa per tanaman diperlihatkan pada Gambar 10.

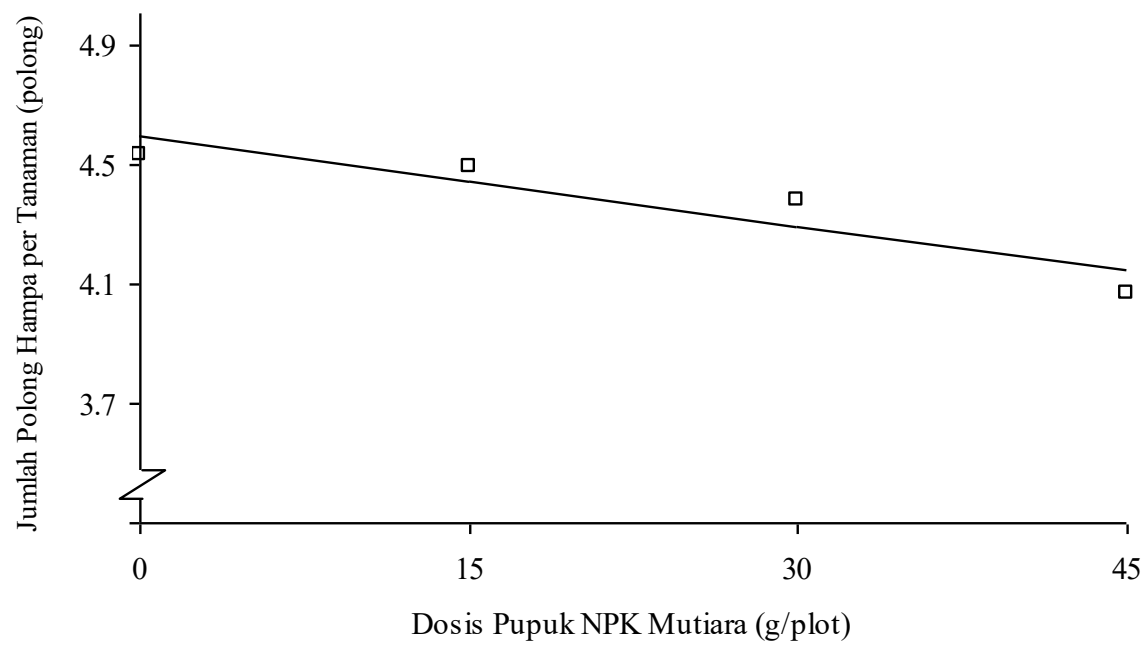

Gambar 10. Kurva Respon Pengaruh Pemberian Pupuk NPK Mutiara terhadap Jumlah Polong Hampa per Tanaman

Dari Gambar 10 terlihat bahwa hampa tertinggi terdapat pada semakin tinggi pemberian pupuk perlakuan $\mathrm{B}_{3}$ dan terendah pada $\mathrm{B}_{1}$.

NPK Mutiara maka jumlah polong hampa per tanaman semakin menurun mengikuti kurva regresi linier negatif dengan nilai $\mathrm{r}$ sebesar 0.92. Peningkatan pemberian pupuk NPK Mutiara sebesar $1 \mathrm{~g} /$ plot maka jumlah polong hampa per tanaman meningkat 0.01 polong.

Tabel 7 juga menunjukkan bahwa pada perlakuan banyaknya biji per lubang tanam, jumlah polong

\section{Jumlah Polong Total per Tanaman (polong)}

Rataan jumlah polong total per tanaman akibat perlakuan pemberian pupuk NPK Mutiara dan banyaknya biji per lubang tanam disajikan pada Tabel 7. 
Tabel 7. Rataan Jumlah Polong Total per Tanaman akibat Perlakuan Pemberian Pupuk NPK Mutiara dan Banyaknya Biji per Lubang Tanam (polong)

\begin{tabular}{ccccc}
\hline Perlakuan & $\mathrm{B}_{1}$ & $\mathrm{~B}_{2}$ & $\mathrm{~B}_{3}$ & Rataan \\
\hline $\mathrm{N}_{0}$ & 21.07 & 20.33 & 19.47 & $20.29 \mathrm{a}$ \\
$\mathrm{N}_{1}$ & 22.87 & 22.07 & 19.93 & $21.62 \mathrm{~b}$ \\
$\mathrm{~N}_{2}$ & 22.87 & 22.67 & 20.53 & $22.02 \mathrm{~b}$ \\
$\mathrm{~N}_{3}$ & 22.87 & 22.07 & 21.67 & $22.20 \mathrm{~b}$ \\
\hline Rataan & $22.42 \mathrm{a}$ & $21.78 \mathrm{a}$ & $20.40 \mathrm{~b}$ & \\
\hline
\end{tabular}

Keterangan: Angka yang diikuti oleh huruf yang sama dalam kolom dan kelompok perlakuan yang sama berartitidak berbeda pada ujiDuncan taraf uji $5 \%$

Tabel 7 menunjukkan bahwa pada perlakuan pemberian pupuk NPK Mutiara, jumlah polong total per tanaman terbanyak terdapat pada perlakuan $\mathrm{N}_{3}$ berbeda nyata dengan $\mathrm{N}_{0}$, tetapi berbeda tidak nyata dengan
$\mathrm{N}_{1}$ dan $\mathrm{N}_{2}$. Hubungan antara pemberian pupuk NPK Mutiara dengan jumlah polong total per tanaman diperlihatkan pada Gambar 11.

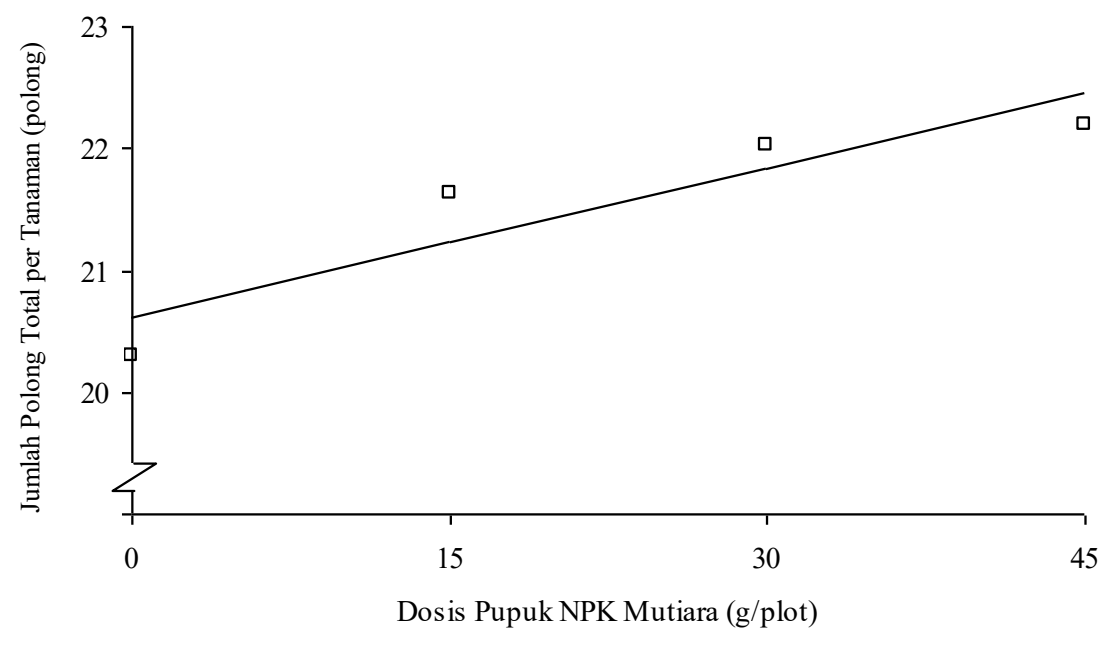

Gambar 11. Kurva Respon Pengaruh Pemberian Pupuk NPK Mutiara terhadap Jumlah Polong Total per Tanaman

Dari Gambar 11 terlihat bahwa semakin tinggi pemberian pupuk NPK Mutiara maka jumlah polong total per tanaman semakin meningkat mengikuti kurva regresi linier positif dengan nilai $r$ sebesar 0.92 . Peningkatan pemberian pupuk NPK Mutiara sebesar $1 \mathrm{~g} / \mathrm{plot}$ maka jumlah polong total per tanaman meningkat 0.04 polong.
Tabel 8 juga menunjukkan bahwa pada perlakuan banyaknya biji per lubang tanam, jumlah polong total per tanaman terbanyak terdapat pada perlakuan $B_{1}$ berbeda nyata dengan $B_{3}$, tetapi berbeda tidak nyata dengan $\mathrm{B}_{2}$. Jumlah polong total per tanaman pada perlakuan $\mathrm{B}_{2}$ berbeda nyata dengan $\mathrm{B}_{1}$. Hubungan antara banyaknya biji per lubang tanam 
dengan jumlah polong total per

12. tanaman diperlihatkan pada Gambar

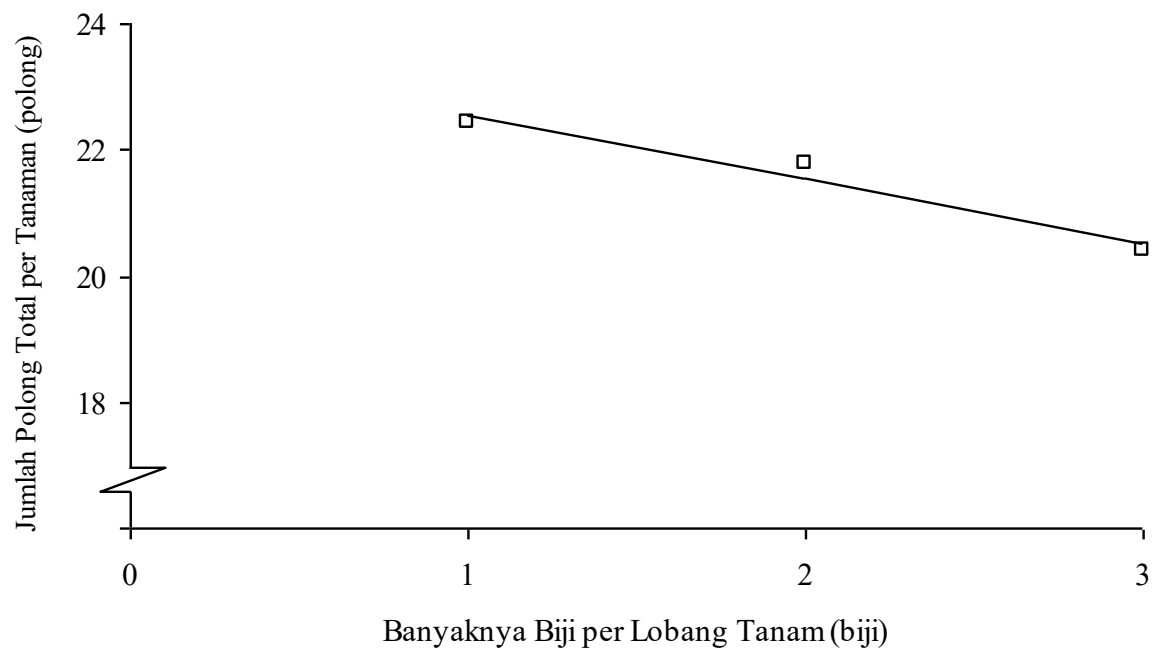

Gambar 12. Kurva Respon Pengaruh Banyaknya Biji per Lubang Tanam terhadap Jumlah Polong Total per Tanaman

Dari Gambar 12 terlihat bahwa

tanaman menurun sebesar 1.01 semakin banyaknya biji per lubang polong.

tanam maka jumlah polong total per tanaman semakin meningkat mengikuti kurva regresi linear negatif dengan nilai $\mathrm{r}$ sebesar -0.98 . Peningkatan jumlah biji per lubang tanam sebesar 1 biji/lubang tanam maka jumlah polong total per

\section{Bobot Polong per Plot (g)}

Rataan bobot polong per plot akibat perlakuan pemberian pupuk NPK Mutiara dan banyaknya biji per lubang tanam disajikan pada Tabel 8.

Tabel 8. Rataan Bobot Polong per Plot akibat Perlakuan Pemberian Pupuk NPK Mutiara dan Banyaknya Biji per Lubang Tanam (g)

\begin{tabular}{ccccc}
\hline Perlakuan & $\mathrm{B}_{1}$ & $\mathrm{~B}_{2}$ & $\mathrm{~B}_{3}$ & Rataan \\
\hline $\mathrm{N}_{0}$ & 440.00 & 458.33 & 406.67 & $435.00 \mathrm{a}$ \\
$\mathrm{N}_{1}$ & 513.33 & 579.33 & 480.67 & $524.44 \mathrm{~b}$ \\
$\mathrm{~N}_{2}$ & 581.33 & 656.00 & 516.67 & $584.67 \mathrm{~b}$ \\
$\mathrm{~N}_{3}$ & 592.67 & 594.00 & 535.00 & $573.89 \mathrm{~b}$ \\
\hline Rataan & $531.83 \mathrm{~b}$ & $571.92 \mathrm{~b}$ & $484.75 \mathrm{a}$ & \\
\hline
\end{tabular}

Keterangan: Angka yang diikuti oleh huruf yang sama dalam kolom dan kelompok perlakuan yang sama berartitidak berbeda pada uji Duncan taraf uji $5 \%$

Tabel 8 menunjukkan bahwa pada perlakuan pemberian pupuk NPK Mutiara, bobot polong per plot terberat terdapat pada perlakuan $\mathrm{N}_{3}$ berbeda nyata dengan $\mathrm{N}_{0}$, tetapi berbeda tidak nyata dengan $\mathrm{N}_{1}$ dan $\mathrm{N}_{2}$. Hubungan antara pemberian pupuk NPK Mutiara dengan bobot 
polong per plot diperlihatkan pada Gambar 13.

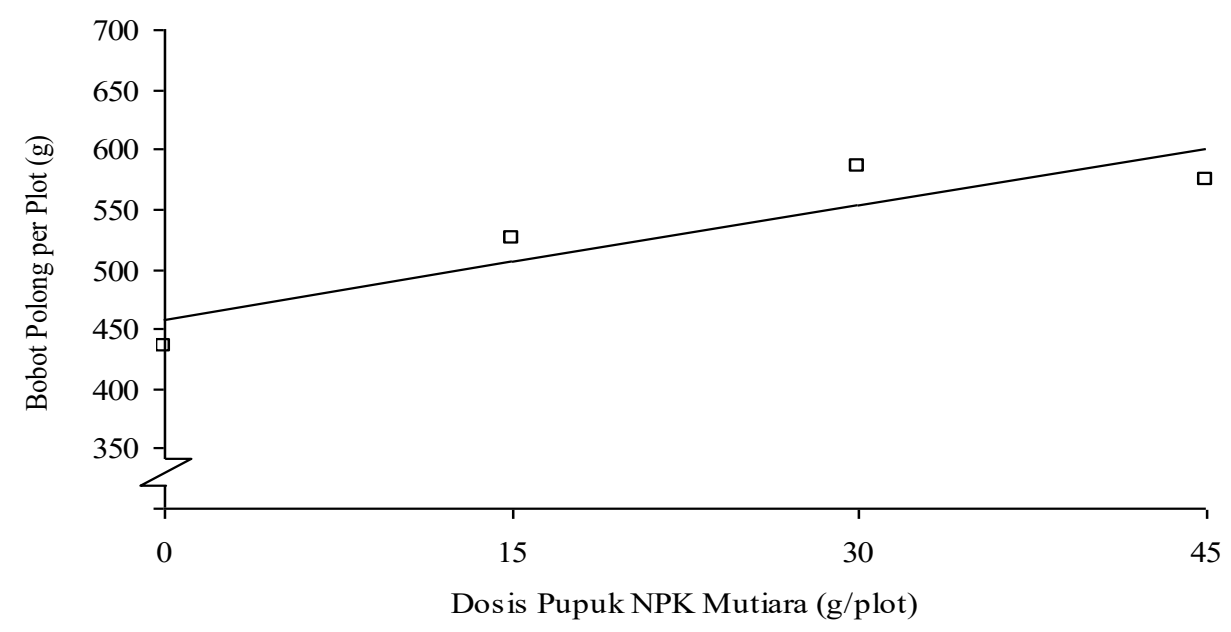

Gambar 13. Kurva Respon Pengaruh Pemberian Pupuk NPK Mutiara terhadap Bobot Polong per Plot

Dari Gambar 13 terlihat bahwa semakin tinggi pemberian pupuk NPK Mutiara maka bobot polong per plot semakin meningkat mengikuti kurva regresi linier positif dengan nilai $r$ sebesar 0.90 . Peningkatan pemberian pupuk NPK Mutiara sebesar $1 \mathrm{~g} /$ plot maka bobot polong per plot meningkat $3.18 \mathrm{~g}$.

Tabel 9 juga menunjukkan bahwa pada perlakuan banyaknya biji per lubang tanam, bobot polong per plot terberat terdapat pada perlakuan $\mathrm{B}_{2}$ berbeda nyata dengan $\mathrm{B}_{3}$, tetapi berbeda tidak nyata dengan $\mathrm{B}_{1}$. Bobot polong per plot pada perlakuan $\mathrm{B}_{1}$ berbeda nyata dengan $\mathrm{B}_{3}$. Hubungan antara banyaknya biji per lubang tanam dengan bobot polong per plot diperlihatkan pada Gambar 14.

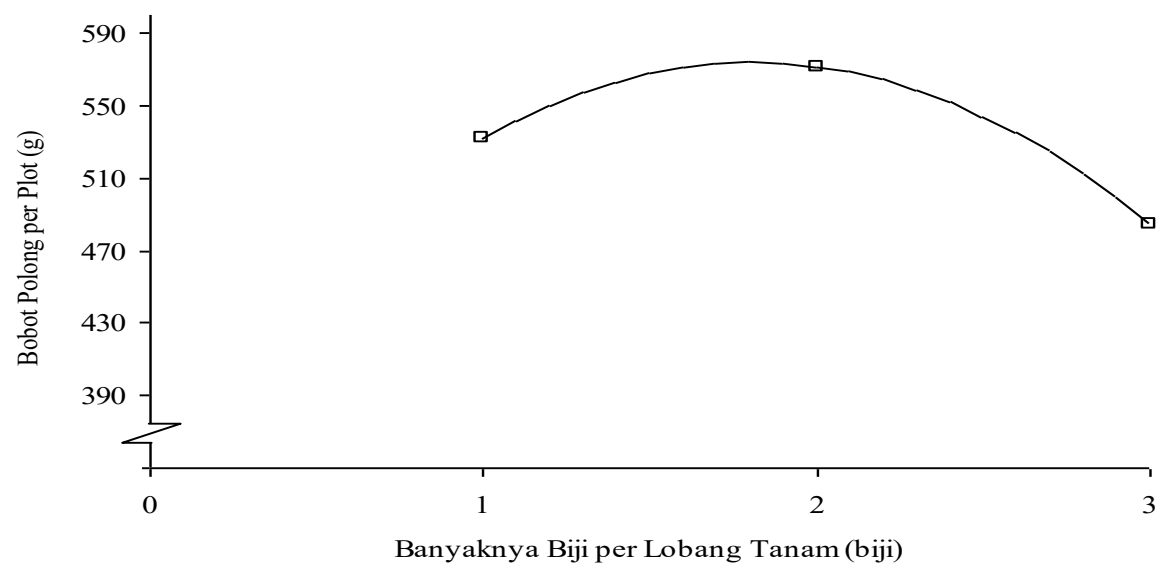

Gambar 14. Kurva Respon Pengaruh Banyaknya Biji per Lubang Tanam terhadap Bobot Polong per Plot 
Dari Gambar 14 terlihat bahwa dengan jumlah biji per lubang tanam sebanyak 2 biji per lubang tanam menghasilkan bobot polong per plot maksimum sebesar $574.09 \mathrm{~g}$.

\section{Bobot 100 Biji (g)}

Rataan bobot 100 biji akibat perlakuan pemberian pupuk NPK Mutiara dan banyaknya biji per lubang tanam disajikan pada Tabel 9.

Tabel 9. Rataan Bobot 100 Biji akibat Perlakuan Pemberian Pupuk NPK Mutiara dan Banyaknya Biji per Lubang Tanam (g)

\begin{tabular}{ccccc}
\hline Perlakuan & $\mathrm{B}_{1}$ & $\mathrm{~B}_{2}$ & $\mathrm{~B}_{3}$ & Rataan \\
\hline $\mathrm{N}_{0}$ & 43.00 & 42.67 & 42.00 & $42.56 \mathrm{a}$ \\
$\mathrm{N}_{1}$ & 43.33 & 45.33 & 42.00 & $43.56 \mathrm{ab}$ \\
$\mathrm{N}_{2}$ & 44.33 & 47.00 & 42.33 & $44.56 \mathrm{~b}$ \\
$\mathrm{~N}_{3}$ & 47.33 & 48.33 & 44.00 & $46.56 \mathrm{c}$ \\
\hline Rataan & $44.50 \mathrm{~b}$ & $45.83 \mathrm{~b}$ & $42.58 \mathrm{a}$ & \\
\hline
\end{tabular}

Keterangan: Angka yang diikuti oleh huruf yang sama dalam kolom dan kelompok perlakuan yang sama berartitidak berbeda pada ujiDuncan taraf uji $5 \%$

Tabel 9 menunjukkan bahwa pada perlakuan pemberian pupuk NPK Mutiara, bobot 100 biji terdapat pada perlakuan $\mathrm{N}_{3}$ berbeda nyata dengan $\mathrm{N}_{0}, \mathrm{~N}_{1}$ dan $\mathrm{N}_{2}$. Bobot 100 biji pada perlakuan $\mathrm{N}_{2}$ berbeda nyata dengan
$\mathrm{N}_{0}$, tetapi berbeda tidak nyata dengan $\mathrm{N}_{1}$. Bobot 100 biji pada perlakuan $\mathrm{N}_{1}$ berbeda tidak nyata dengan $\mathrm{N}_{0}$. Hubungan antara pemberian pupuk NPK Mutiara dengan bobot 100 biji diperlihatkan pada Gambar 15.

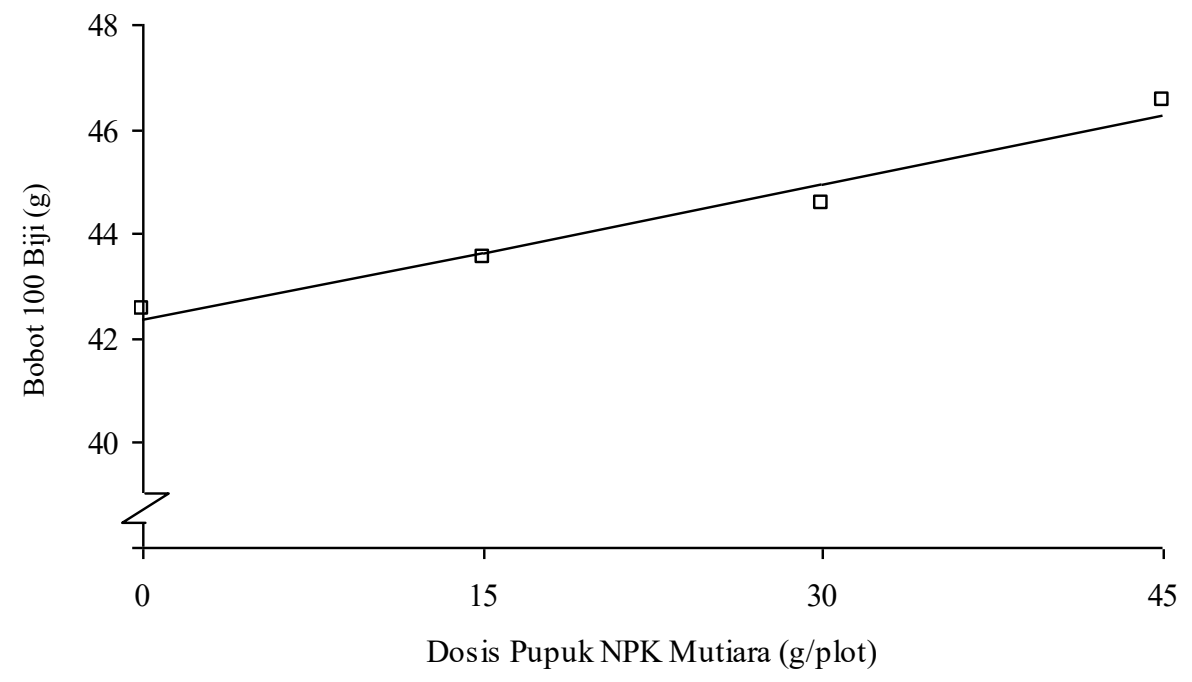

Gambar 15. Kurva Respon Pengaruh Pemberian Pupuk NPK Mutiara terhadap Bobot 100 Biji

Dari Gambar 15 terlihat bahwa NPK Mutiara maka bobot 100 biji semakin tinggi pemberian pupuk semakin meningkat mengikuti kurva 
regresi linier positif dengan nilai $r$ sebesar 0.98. Peningkatan pemberian pupuk NPK Mutiara sebesar $1 \mathrm{~g} /$ plot maka bobot 100 biji meningkat 0.09 g.

Tabel 10 juga menunjukkan bahwa pada perlakuan banyaknya biji per lubang tanam, bobot 100 biji terberat terdapat pada perlakuan $\mathrm{B}_{2}$ berbeda nyata dengan $\mathrm{B}_{3}$, tetapi berbeda tidak nyata dengan $\mathrm{B}_{1}$. Bobot 100 biji pada perlakuan $\mathrm{B}_{1}$ berbeda nyata dengan $B_{3}$. Hubungan antara banyaknya biji per lubang tanam dengan bobot 100 biji diperlihatkan pada Gambar 16.

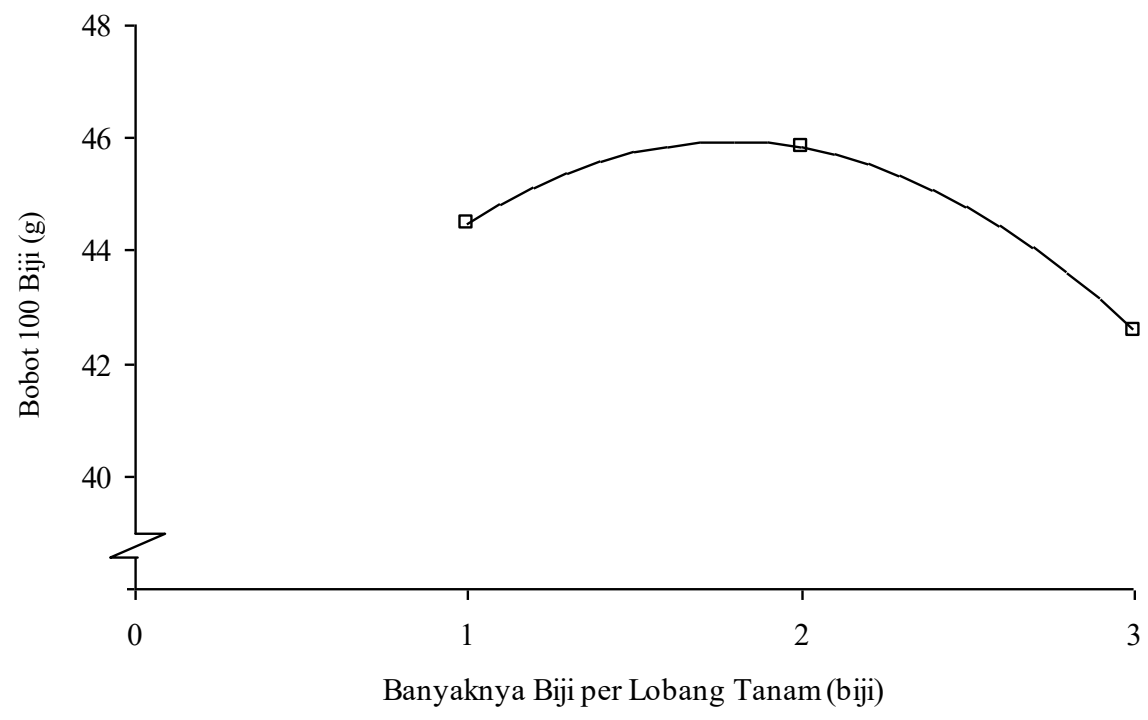

Gambar 16. Kurva Respon Pengaruh Banyaknya Biji per Lubang Tanam terhadap Bobot 100 Biji

Dari Gambar 16 terlihat bahwa dengan jumlah biji per lubang tanam sebanyak 2 biji per lubang tanam menghasilkan bobot 100 biji maksimum sebesar $45.93 \mathrm{~g}$.

\section{HASIL DAN PEMBAHASAN}

Pengaruh Pemberian Pupuk NPK

Mutiara terhadap

Pertumbuhan dan Produksi

Tanaman Kacang Tanah

Hasil penelitian menunjukkan bahwa pemberian pupuk NPK mutiara nyata meningkatkan pertumbuhan tinggi tanaman dan jumlah cabang utama. Adanya pengaruh terhadap tinggi tanaman disebabkan karena pupuk NPK mampu menyediakan hara Nitrogen dalam jumlah yang cukup dan tersedia dalam memenuhi kebutuhan unsur hara tanaman pada masa vegetatif.. Hasil penelitian Hendri (2015) menyatakan bahwa unsur hara $\mathrm{N}$ diperlukan oleh tanaman untuk pembentukan klorofil, dan merangsang pertumbuhan vegetatif tanaman seperti batang, cabang, dan daun. Tinggi tanaman tertinggi dialami oleh tanaman akibat perlakuan menggunakan pupuk NPK hal ini terjadi karena tanaman yang diberi pupuk akan memliki kandungan unsur hara yang dapat membantu mempercepat pertumbuhan tanaman. Hal ini 
diduga disebabkan pupuk NPK dapat menyeimbangi kebutuhan unsur hara pada tanaman.

Hasil penelitian menunjukkan bahwa pemberian pupuk NPK nyata meningkatkan jumlah ginogor, jumlah polong berisi per tanaman, jumlah polong total per tanaman, bobot polong per plot dan bobot 100 biji. Hal ini disebabkan pemberian pupuk NPK dapat meningkatkan suplai unsur hara $\mathrm{N}, \mathrm{P}$ dan $\mathrm{K}$ terhadap tanaman. Syarief (2006) menyatakan bahwa tersedianya unsur hara yang cukup pada saat pertumbuhan menyebabkan metabolisme tanaman lebih aktif sehingga proses pemanjangan, pembelahan dan diferensiasi sel akan lebih baik yang akhirnya dapat mendorong peningkatan produksi. Menurut Jumin (2005) bahwa pertumbuhan hingga hasil produksi akan berhasil dengan sempurna apabila keperluan nutrisi atau unsur hara bagi tanaman mencukupi. Pupuk NPK yang diaplikasikan dengan cara melarutkan dengan air dan menyemprotkan pada tanaman lebih efektif diserap tanaman lebih cepat sehingga mampu menyuplai kebutuhan tanaman.

Berdasarkan hasil penelitian yang dilakukan produksi polong segar terbaik diperoleh pada perlakuan $\mathrm{N}_{3}$ (dosis $45 \mathrm{~g} / \mathrm{plot}$ ) yaitu $573.89 \mathrm{~g} /$ plot atau setara dengan 3,83 ton/ha. Secara umum dapat disimpulkan bahwa pemberian pupuk NPK Mutiara dapat meningkatkan pertumbuhan dan produksi tanaman kacang tanah. Hal ini disebabkan unsur $\mathrm{N}, \mathrm{P}$, dan $\mathrm{K}$ dibutuhkan oleh tanaman dari fase vegetatif hingga generatif. Semakin tinggi dosis pupuk yang diberikan semakin tinggi hasil kacang tanah yang diperoleh. Menurut Marzuki (2007) bahwa unsur $\mathrm{N}, \mathrm{P}$ dan $\mathrm{K}$ memiliki fungsi masing-masing yang sama pentingnya bagi pertumbuhan tanaman, baik pada fase vegetatif maupun fase generatif.

\section{Pengaruh Banyaknya Biji per \\ Lubang Tanam terhadap Pertumbuhan dan Produksi Tanaman Kacang Tanah \\ Hasil penelitian menunjukkan} bahwa banyaknya biji per lubang jumlah cabang utama dan umur berbunga tanaman. Pengaturan jumlah biji per lubang tanam bertujuan untuk mengurangi persaingan dalam mendapatkan faktor tumbuh (cahaya matahari, air, dan unsur hara) sehingga dapat meningkatkan proses fotosintesis. Dengan meningkatnya proses fotosintesis maka fotosintat yang dihasilkan menjadi lebih tinggi yang didistribusikan ke seluruh bagian tanaman. Oleh karena itu pertumbuhan tanaman menjadi lebih baik. Pertumbuhan tanaman yang baik akan mempengaruhi hasil tanaman, yaitu berat polong isi segar. Menurut Mahmud (2015), jumlah benih per lubang tanam berpengaruh pada pertumbuhan tanaman karena akan terjadi persaingan dalam mendapatkan cahaya matahari, air dan unsur hara, sehingga mempengaruhi produksi.

Hasil penelitian menunjukkan bahwa perlakuan banyaknya biji per lubang tanaman per lubang berbeda nyata terhadap jumlah polong berisi per tanaman, jumlah polong selurunya, berat polong segar per tanaman dan bobot 100 biji. Bunga yang telah diserbuki akan berubah 
menjadi ginofor. Ginofor akan tumbuh ke arah bawah. Setelah menembus ke dalam tanah, ginofor akan membentuk bakal buah pada ujungnya. Tidak semua ginofor dapat berkembang menjadi polong isi, karena pengaruh berbagai hal, di antaranya lingkungan tumbuh. Menurut Adisarwanto (2003) bahwa fase kritis tanaman jenis polongpolongan yaitu periode pembentukan bunga dan polong. Bilamana tanaman ditanam pada awal musim hujan, sering kali curah hujan terlalu banyak pada fase berbunga, sehingga mengurangi jumlah polong yang terbentuk.

Hasil penelitian menunjukkan bahwa penggunaan jumlah benih 2 biji per lubang tanam menghasilkan bobot polong per plot dan bobot 100 biji yang lebih tinggi dibandingkan jumlah benih 1 biji per lubang tanam dan 3 biji per lubang tanam. Hal ini disebabkan karena tidak adanya persaingan antar tanaman untuk memperoleh ruang tumbuh, cahaya dan nutrisi dari dalam tanah. Bertambahnya jumlah bibit per lubang tanam cenderung meningkatkan persaingan tanaman, baik antar tanaman dalam satu lubang tanam maupun antar lubang tanam yang akan berdampak pada penurunan jumlah anakan total (Masdar, 2006).

Interaksi antara Pemberian Pupuk NPK Mutiara dan Banyaknya Biji per Lubang Tanam terhadap Pertumbuhan dan Produksi

\section{Tanaman Kacang Tanah}

Hasil analisis sidik ragam menunjukkan bahwa interaksi antara pemberian pupuk NPK Mutiara dan banyaknya biji per lubang tanam berpengaruh tidak nyata terhadap seluruh peubah yang diamati. Hal ini disebabkan kedua perlakuan tidak memiliki hubungan yang sinergi terhadap pertumbuhan dan produksi tanaman.

Berdasarkan hasil analisis tanah diperoleh kandungan N-total sebesar 0,25 \% (tinggi), P sebesar $0,09 \%$ (rendah) dan K sebesar 0,50 $\%$ (rendah) dengan KTK tanah sebesar 17,84 m.e/100 (sedang) dengan fraksi pasir sebesar $82 \%$, fraksi debu $16 \%$ dan fraksi liat sebesar $2 \%$. Menurut Pusat Penelitian Tanah (1983) bahwa kandungan N-total tanah 0,51 - 0,75 tergolong tinggi. Berdasarkan hasil analisis tersebut jug a dapat diketahui bahwa tanah didominasi oleh fraksi pasir. Hakim dkk. (2005) menyatakan bahwa tanah didominasi oleh partikel berukuran kasar (pasir) akan didominasi oleh pori makro, sebaliknya partikel halus (debu dan liat) akan didominasi oleh pori mikro. Kondisi aerob akan mendorong oksidasi bahan organik menjadi mineral-mineral tanah. Ini berarti bahan organik tanah akan semakin rendah. Tanah bertekstur kasar (pasir) mempunyai kandungan bahan organik dan kapasitas menahan air sangat rendah. Hal ini menunjukkan bahwa tanah memiliki sifat fisik yang kurang baik walaupun mengand ung unsur $\mathrm{N}$ yang tinggi.

\section{SIMPULAN DAN SARAN Simpulan}

1. Perlakuan pemberian pupuk NPK Mutiara hingga $45 \mathrm{~g} / \mathrm{plot}$ berpengaruh nyata terhadap tinggi tanaman, jumlah cabang utama, umur berbunga, jumlah ginofor per tanaman, jumlah 
polong hampa per tanaman, jumlah polong total per tanaman, bobot polong per plot dan bobot 100 biji.

2. Perlakuan banyaknya biji per lubang tanam berpengaruh nyata terhadap jumlah cabang utama, umur berbunga, jumlah ginofor per tanaman, jumlah polong total per tanaman, bobot polong per plot dan bobot 100 biji, tetapi berpengaruh tidak nyata terhadap tinggi tanaman dan jumlah polong hampa per tanaman.

3. Perlakuan kombinasi pemberian pupuk NPK Mutiara dan banyaknya biji per lubang tanam tidak berpengaruh nyata terhadap pertumbuhan dan produksi kacang tanah.

\section{Saran}

1. Untuk meningkatkan pertumbuhan dan produksi tanaman kacang tanah disarankan dengan menggunakan pemberian pupuk NPK Mutiara dengan dosis 45 g/plot.

2. Untuk meningkatkan pertumbuhan dan produksi tanaman kacang tanah didsarankan dengan menggunakan jumlah biji 2 per lubang tanam.

\section{DAFTAR PUSTAKA}

Adisarwanto, T. 2003. Meningkatkan Produksi Kacang Tanah di Lahan Sawah dan Lahan Kering. Penebar Swadaya. Jakarta.

Badan Pusat Statistik. 2019. Sumatera Utara dalam
Angka Tahun 2018. Badan

Pusat Statistik Sumatera Utara. Medan.

Fahmi, N. 2014. Pengaruh Pupuk Organik dan Anorganik terhadap Pertumbuhan dan Hasil Kedelai (Glycine max (L.) Merril). J. Floratek 9: 53-62.

Gobel, M. 2015. Pengaruh Waktu Penyiangan dan Jumlah Benih Per Lubang Tanam terhadap Pertumbuhan dan Kacang Tanah (Arachis hypogaea L.) Skripsi. Fakultas Pertanian Universitas Gorontalo. Gorontalo.

Hendri, M. 2015. Pengaruh Pupuk Kandang Sapi dan Pupuk MPK Mutiara terhadap Pertumbuhan dan Hasil Tanaman Terung Ungu (Solanum melongena L.). Jurnal Agrivor Vol 14 (2).

Jumin. H. B. 2005. Dasar-dasar Agronomi. Raja Grafindo Perseda. Jakarta.

Lakitan, B. 2011. Dasar-Dasar Fisiologi Tumbuhan. PT. Raja Grafindo Persada, Jakarta.

Lingga, P. dan Marsono. 2013. Petunjuk Penggunaan Pupuk. Penebar Swadaya. Jakarta.

Mahmud. 2015. Pengaruh Jumlah Bibit Dan Dosis Pupuk NPK Phonska Terhadap Pertumbuhan Dan Produksi 
Tanaman Padi Sawah (Oryza sativa, L.). Laporan Penelitian. Jurusan Agroteknologi, Fakultas Pertanian Universitas Negeri Gorontalo. $11 \mathrm{~h}$.

Marzuki, R. 2009. Bertanam Kacang Tanah. Penebar Swadaya. Jakarta.

Masdar. 2006. Pengaruh Jumlah Bibit Tanam dan Umur Bibit terhadap Pertumbuhan Reproduktif Tanaman Padi pada Irigasi tanpa Penggenangan. Jurnal Dinamika Pertanian 21 (2):121 - 126.

Najiyati, S. 1994. Palawija, Budidaya dan Analisis Usahatani. Penebar Swadaya. Jakarta.

Novizan. 2010. Petunjuk Pempukan yang Efektif. AgroMedia Pustaka. Jakarta.

Raharja A., S. Endah dan Heru D. P. 2018. Pengaruh Pengolahan Tanah dan Dosis Pupuk NPK terhadap Pertumbuhan dan Hasil Kacang Tanah (Arachis hypogea L.). Jurnal Fakultas Pertanian. Universitas Sarjanawiyata Tamansiswa Yogyakarta.

Rukmana. 2007. Budidaya Kacang Tanah. Kanisius. Yogyakarta.

Suprapto, A., H. Rianto, Historiawati dan W. Juliprijanto. 2018. Peningkatan Produktivitas
Tanah Sawah dan Kering Dengan Budidaya Tanaman Kacang Tanah Di Desa Balesari, Kecamatan Windusari, Kabupaten Magelang. The $7^{\text {th }}$ University Research Colloquium 2018 STIKES PKU Muhammadiyah Surakarta.

Wirawan, D. A., G. Haryono, Y. E. Susilowati. 2018. Pengaruh Jumlah Tanaman per Lubang Tanam dan Jarak Tanam terhadap Hasil Tanaman Kacang Tanah (Arachis hypogea L.) Varietas Kancil. Jurnal Ilmu Pertanian Tropika dan Subtropika 3 (1) : $5-8$.

Zulhaedar, F., M. Nazam dan A. Suriadi. 2016. Dosis Pemupukan NPK Optimal Kacang Tanah pada Tanah Typic Epiaquept. Prosiding Seminar Hasil Penelitian Tanaman Aneka Kacang dan Umbi. Balai Pengkajian Teknologi Pertanian Nusa Tenggara Barat. 